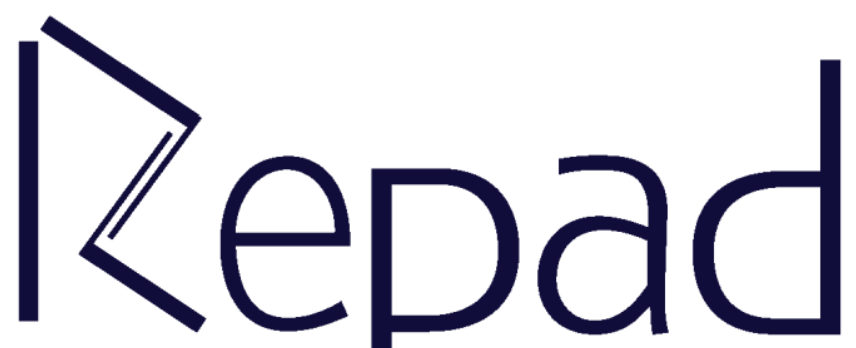

Revista Estudos e

Pesquisas em Administração

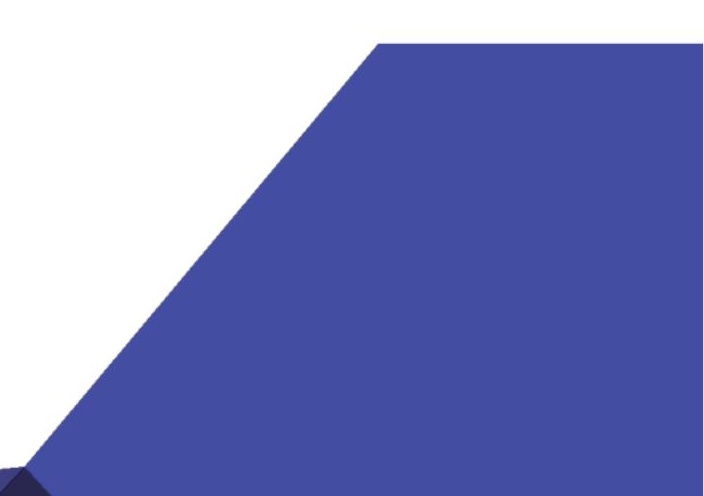




\section{Foco e Escopo}

A Revista Estudos e Pesquisas em Administração (Repad), publicada quadrimestralmente, é uma iniciativa do Curso de Administração da UFMT, Câmpus Rondonópolis, e tem a finalidade de publicar e divulgar ensaios teóricos e pesquisas teóricoempíricas já finalizados, de modo a disseminar o conhecimento científico entre acadêmicos e profissionais da área de administração e afins.

\section{Editor}

Prof. Dr. André Luís Janzkovski Cardoso

\section{Conselho Editorial}

André Luís Janzkovski Cardoso

Fernanda Pereira Silva

Heitor Lopes Ferreira

Ivânia Freire da Silva

Maurício Alves Rodrigues Pugas

Marcia Juliana d'Angelo

Neide Santos da Silva

Paulo Henrique Martins Desidério

Rodrigo Milano de Lucena

Roseli Aparecida dos Reis

\section{Editores de Texto}

Karine Lopes Ono

Ivânia Freire da Silva

Rodrigo Milano de Lucena

Roseli Aparecida dos Reis

Sandra Gimenes

\section{Editores de Layout}

Carlos Sérgio Rodrigues Queiroz

Douglas Reginatto

Jennifer Nogueira Feitosa Silva

Serifo Salum

\section{Design gráfico}

Execução: Caroline Pedrozo

Supervisão de Design: Jessica Bastos

Secretaria de Comunicação e Multimeios

\section{Correspondências}

Av. dos Estudantes, 5005, Rondonópolis - MT

CEP 78735-901

Telefone: (66) 3410-4070

Site:

http://periodicoscientificos.ufmt.br/ojs/index.php/repad E-mail:

repadufmt@gmail.com

\section{Avaliadores e Pareceristas}

Prof. Dr. André Luís Janzkovski Cardoso, UFMT

Prof. Dr. Avilo Roberto Magalhães, UFMT

Prof. Dr. Carlos Eduardo Freitas, UFMT

Prof. Dr. Leandro Pessoa de Lucena, UFMT

Prof. Dr. Orlando Ramos Nascimento Jr., Uneal

Prof. Dr. Paulo Henrique Martins Desidério, UFMT

Prof. Dr. Rony Ahlfeldt, PUC-PR

Prof. Esp. Diogo Barbosa Leite, IFMT

Prof. Esp. José Alan Barbosa da Silva, Consultor

Prof. Me. Heitor Lopes Ferreira, UFMT

Prof. Me. Maurício Alves Rodrigues Pugas, UFMT

Prof. Me. Rodrigo Milano de Lucena, UFMT

Profa. Dra. Cecilia Arlene Moraes, UFMT

Profa. Dra. Fernanda Pereira Silva, UFMT

Profa. Dra. Ivana Aparecida Ferrer Silva, UFMT

Profa. Dra. Marcia Juliana d'Angelo, Fucape

Profa. Dra. Marinês Taffarel, Unicentro

Profa. Dra. Priscila de Oliveira Xavier Scudder, UFMT

Profa. Dra. Suzimeri Vilas Boas Pescador, Unipar

Profa. Ma. Danieli Artuzi Pes Backes, UFMT

Profa. Ma. Idineia Bressan, Faculdade Católica-MT

Profa. Ma. Ivânia Freire da Silva, UFMT

Profa. Ma. Milady da Silva Oliveira, UFMT

Profa. Ma. Neide Santos da Silva, UFMT

Profa. Ma. Rosane Bueno Machado, Consultora

Profa. Ma. Roseli Aparecida dos Reis, UFMT

Profa. Ma. Sarah Caroline de Deus Pereira, Advogada

Profa. Ma. Valéria Sun Hwa Mazucato, Anhanguera-MS
REPAD, v. 2, n 2, 2018 - Rondonópolis

UFMT/CUR, 2018

Quadrimestral

ISSN 2594-7559

1. Administração - Periódicos.

ed. 


\section{Prezados leitores}

No primeiro artigo, um grupo de autores, liderado por Carlos Sérgio Rodrigues Queiroz, realizou uma pesquisa para analisar as publicações sobre Gestão da Diversidade disponíveis na base de dados da plataforma Spell, no período entre 1991 e 2017. O artigo indicou os autores que mais publicaram, as instituições de ensino superior associadas a esses autores e as principais revistas, utilizando uma pesquisa bibliométrica que selecionou 128 artigos que foram organizados em categorias (revista, autores, IES, tema, abordagem de pesquisa). Os resultados gerados indicaram a importância competitiva e estratégica para as organizações à medida que estudam diversidade e o aprendizado organizacional. O segundo artigo, escrito por Mirella Vicente de Carvalho, Diogo Barbosa Leite e Silvana Santos da Cruz, discute o que os pais valorizam na busca de uma escola e/ou berçário para seus filhos. O objetivo fundamental foi investigar o processo de escolha e o comportamento de compra dos clientes da escola analisada. Os principais resultados estão relacionados às peculiaridades do segmento, sendo os grupos de referência extremamente importantes para esses consumidores. Os autores descobriram que mais do que por meio da comunicação, esses consumidores são guiados por indicações de pessoas para quem eles relatam credibilidade. Eles também descobriram que esses pais, diferentemente do que a própria diretora da escola disse, não buscam status social quando buscam a escola de seus filhos, mas instituições que cuidam da metodologia educacional. Camila Bittencourt do Nascimento e Arilda Magna Campagnaro Teixeira buscaram identificar as competências percebidas pelos alunos de Administração de Empresas no estado do Maranhão que foram desenvolvidas durante seus cursos. As autoras utilizaram uma pesquisa de caráter descritivo, com corte transversal, por meio da coleta de dados primários por acessibilidade. Os resultados foram obtidos por meio de estatística descritiva e regressão linear múltipla. As estatísticas descritivas mostraram que alguns alunos das IES Públicas e Particulares indicaram dispersão entre as opiniões. As estimativas da regressão mostraram que, para as IES Públicas, apenas o Perfil Profissiográfico se mostrou estatisticamente significante para explicar o perfil de egressos, mas para as IES Privadas, as variáveis Perfil Profissiográfico, Descrição do trabalho e "trabalhar na área administrativa" apresentaram significância estatística, ao nível de 5\% de confiança. Esses resultados sugerem que os alunos da IES pública percebem menos competências e habilidades que estão lhes sendo desenvolvidas do que os alunos das IES Privadas. O quarto artigo, conduzido por Danieli Artuzi Pes Backes e seus alunos, identificou as relações entre os pesquisadores de Inovação dos Programas de Pós-graduação em Administração (PPGAs) strictosensu brasileiros, usando como base a abordagem teórico-metodológica da Análise de Redes Sociais (ARS), utilizando o Ucinet 6 e NetDraw 2160 como software. Os resultados mostraram relações fracas para a formação da rede de coautores de Inovação, que alguns pesquisadores atuam como nós centrais da produção científica intra-institucional e que outros atuam como pontes interinstitucionais, mas que uma parcela significativa de autores não possui nenhum vínculo com os pesquisadores da rede estudada, deixando uma lacuna a ser pesquisada em estudos futuros. João Bosco Arbues Carneiro Júnior, Elahíne Santos de Moraes, Ramón Luiz Arenhardt e Sofia Inês Niveiros tiveram como objetivo estimar o valor de um hotel localizado no Distrito Industrial de Rondonópolis-MT utilizando múltiplos de mercado e fluxo de caixa descontado como metodologias. Os autores encontraram discrepâncias nos resultados da avaliação em relação aos métodos utilizados, e enfatizaram a superioridade do fluxo de caixa descontado. A pesquisa parece ser relevante para os proprietários da empresa, pois eles visualizaram o valor de sua organização e identificaram qual melhor método representava esses valores. José de Arimathea Cabral apresentou uma análise dos procedimentos de contratação de serviços públicos terceirizados na Universidade Federal de Pernambuco. A abordagem qualitativa foi realizada por meio de pesquisa bibliográfica e documental, e o resultado mostrou que a contratação pública não é tarefa simples e não se concretiza em tempo hábil, que requer profundo conhecimento das partes envolvidas e, ainda enfrenta uma burocracia lenta e onerosa. Rafaela Simoes Egito e Wilka Ferreira Monteiro discutiram um aspecto cultural na sociedade brasileira, o chamado "jeitinho brasileiro". O estudo confrontou as abordagens de vários autores que já discutiram o assunto e tentou compreender se afinal poderia ser cogitado como alternativa válida o uso desse dito "jeitinho" como uma saída viável e aceitável na resolução dos problemas internos e característicos da Gestão Pública, ou se, de modo algum poderia ser tolerado tal comportamento, uma vez que se configuraria como grave afronta e transgressão aos direitos e garantias fundamentais expressados pelos princípios da Administração Pública. Para tanto, realizaram uma pesquisa sobre o tema na literatura especializada e, de maneira geral, percebendo-se que o jeitinho pode ser analisado como produto do formalismo de forma positiva ou negativa, de acordo com a conveniência social. No último artigo, Thais Santos Martins discutiu o tema da evasão do ensino superior em 18 cursos do Núcleo de Educação a Distância da Anhanguera Uniderp em Rondonópolis-MT. Modelos estatísticos foram utilizados para a análise fatorial e os comparativos entre médias. Os resultados indicaram que há diferenças, estatisticamente significativas a um nível de 0,05 , entre as razões de evasão e a situação quando o aluno estudava, o estado civil, e que não houve diferenças, estatisticamente significativas, entre as razões de evasão e o semestre, o curso, o gênero e o tipo de moradia. Os dados qualitativos apresentaram algumas razões não observadas na análise quantitativa. A autora indicou que os resultados da análise quantitativa e qualitativa foram discutidos em conjunto, com o objetivo de reforçar as descobertas da pesquisa.

Desejamos que os resultados das pesquisas aqui apresentadas sirvam de base para novos artigos. Prof. Dr. André Luís Janzkovski Cardoso 
Editorial

ANÁLISE DA LITERATURA DA BASE DE PERIÓDICOS SPELL SOBRE A TEMÁTICA GESTÃO DA DIVERSIDADE
Carlos Sérgio Rodrigues Queiroz, Geice Souza dos Santos, Luciene de Jesus e Silva Soares, Vanessa da Silva Ossuna, Marciane Silva Pereira
EM BUSCA DA ESCOLA IDEAL: Os motivos que pesam na hora da melhor escolha
Mirella Vicente de Carvalho, Diogo Barbosa Leite, Silvana Santos da Cruz
COMPETÊNCIAS DO ADMINISTRADOR DESENVOLVIDAS DURANTE A FORMAÇÃO ACADÊMICA NA PERCEPÇÃO DOS ALUNOS

A FORMAÇÃO DE REDES DE COAUTORIA NA PRODUÇÃO CIENTÍFICA DE INOVAÇÃO NOS PPGAS BRASILEIROS Jessica Fernanda Yoshida de Freitas, Manuela de Carvalho e Barbosa, Mateus de Carvalho e Barbosa

João Bosco Arbues Carneiro Junior, Elahíne Santos de Moraes, COM BASE NOS MÉTODOS DOS MÚLTIPLOS DE MERCADO E DO FLUXO DE CAIXA DESCONTADO EM RONDONÓPOLIS-MT

Ramon Luiz Arenhardt, Sofia Ines Niveiros
TERCEIRIZAÇÃO NAS INSTITUIÇÕES processo de licitação para os serviços terceirizados da Universidade Federal de Pernambuco
O JEITINHO BRASILEIRO: Analisando suas características como ferramenta de conveniência e seus prejuízos sociais
128
Rafaela Simoes Egito, Wilka Ferreira Monteiro
EVASÃO UNIVERSITÁRIA NO ENSINO À DISTÂNCIA: Análise de fatores influenciadores 


\title{
ANÁLISE DA LITERATURA DA BASE DE PERIÓDICOS SPELL SOBRE A TEMÁTICA GESTÃO DA DIVERSIDADE
}

\author{
Carlos Sérgio Rodrigues Queiroz, Geice Souza dos Santos, Luciene de Jesus e Silva Soares, \\ Vanessa da Silva Ossuna, Marciane Silva Pereira
}

\section{RESUMO}

O uso do termo diversidade tem sido constante nos estudos organizacionais, isso porque a administração está intimamente relacionada à gestão da diversidade. Assim, a proposta deste artigo tem como objetivo analisar as publicações disponíveis na base da plataforma Spell no período entre 1991 a 2017 sobre o tema Gestão da Diversidade, verificando os períodos, os autores que mais publicaram, as instituições de ensino superior associadas a esses autores e as principais revistas. Para tanto essa é uma pesquisa bibliométrica, com abordagem predominantemente quantitativa e breve aspecto qualitativo. Após os devidos filtros sobre o tema "Gestão da Diversidade" foram selecionados 128 artigos que foram organizados em categorias (revista, autores, IES, tema, abordagem de pesquisa). Os resultados engendrados de fato indicam a importância competitiva e estratégica para as organizações ao estudarem sobre à aprendizagem organizacional. Espera-se que esse levantamento possa demonstrar o cenário da produção científica sobre Gestão da diversidade e proporcionar a reflexão sobre os possíveis cursos e limitações no contexto organizacional e de pesquisas acadêmicas. Como limitação destaca-se a análise em apenas uma base de dados.

Palavras-chave: Gestão de Pessoas, Estudo da Arte, Pesquisa Bibliométrica.

\section{EM BUSCA DA ESCOLA IDEAL: Os motivos que pesam na hora da melhor escolha}

Mirella Vicente de Carvalho, Diogo Barbosa Leite, Silvana Santos da Cruz

\section{RESUMO}

Foi realizada uma investigação numa determinada escola para avaliar quais são os fatores de influência na escolha da instituição de ensino. O objetivo fundamental é pesquisar o comportamento de compra e o processo de escolha dos clientes da instituição analisada. A pesquisa foi dividida em duas partes: a primeira caracteriza-se como estudo de caso, com objetivo explicativo, abordagem qualitativa e utilizando, como instrumento de coleta de dados, um roteiro semiestruturado, que foi aplicado à gestora da escola; a segunda fase se configura como um levantamento, com objetivo descritivo e abordagem quantitativa realizada por meio de um questionário estruturado aplicado aos pais dos alunos. O corte do estudo é transversal e os dados foram coletados no mês de fevereiro de 2017. Os principais resultados se relacionam quanto às peculiaridades do segmento, sendo os grupos de referência os maiores influenciadores destes consumidores. Constatou-se que, mais do que pela comunicação, estes consumidores se pautam por indicações de pessoas as quais reportam credibilidade. Ademais, verificouse que estes pais, diferente do que a própria gestora afirmou, não buscam status quando procuram a escola de seus filhos, mas instituições que zelam pela metodologia educacional.

Palavras-chave: Processo de escolha; Fatores de escolha; Comportamento de compra; Satisfação; Instituição de Ensino. 


\title{
COMPETÊNCIAS DO ADMINISTRADOR DESENVOLVIDAS DURANTE A FORMAÇÃO ACADÊMICA NA PERCEPÇÃO DOS ALUNOS
}

\author{
Camila Bittencourt do Nascimento, Arilda Magna Campagnaro Teixeira
}

\section{RESUMO}

Este estudo teve como objetivo apontar as competências percebidas pelos estudantes de Administração do estado do Maranhão que foram desenvolvidas durante seus cursos. Justifica-se porque acrescentará um ângulo de discussão sobre as qualidades desses cursos - a percepção do aluno sobre suas competências - enquanto a pesquisas existentes concentraram-se nas qualidades dos cursos. Utilizou uma pesquisa quantitativa de caráter descritivo, com corte transversal, por meio da coleta de dados primários por acessibilidade. Os resultados foram obtidos através de estatísticas descritivas e regressão linear múltipla. As estatísticas descritivas apontaram que alguns alunos da IES Pública e das Privadas tenderam a concordar quanto ao desenvolvimento das competências e habilidades; enquanto outros não - os desvios-padrão das médias das respostas indicaram dispersão entre opiniões. As estimativas da regressão, ao nível de 5\% de confiança, apontaram que, para a IES pública, somente o Perfil Profissiográfico mostrou-se estatisticamente significante para explicar o perfil do egresso. Para as IES Privadas, mostraram-se estatisticamente significantes, ao nível de 5\% de confiança, as variáveis, Perfil Profissiográfico, Job Description e "trabalhar na área administrativa". Esses resultados sugerem que os alunos das IES públicas percebem menos competências e habilidades que estão lhes sendo desenvolvidas do que os alunos das IES Privadas.

Palavras-chave: Ensino Superior; Administração; Desenvolvimento de Competências; Percepção dos alunos.

\section{A FORMAÇÃO DE REDES DE COAUTORIAS NA PRODUÇÃO CIENTÍFICA DE INOVAÇÃO NOS PPGAS BRASILEIROS}

\author{
Danieli Artuzi Pes Backes, Jessica Fernanda Yoshida de Freitas, Manuela de
}

Carvalho e Barbosa, Mateus de Carvalho e Barbosa

\section{RESUMO}

Este estudo teve como objetivo identificar as relações entre os pesquisadores de Inovação dos Programas de Pós-graduação em Administração (PPGAs) stricto-sensu brasileiros, usando como base a abordagem teórico-metodológica da Análise de Redes Sociais (ARS). No intuito de mapear as redes de coautoria de produção científica, utilizou-se o software Ucinet 6 e NetDraw 2.160 para geração dos grafos, chegando a resultados que apontaram relações fracas quanto à formação da rede de coautores de Inovação. Entretanto, ficou claro o comportamento proativo de alguns pesquisadores que agem como nós centrais de produção científica intrainstitucional e outros que agem como pontes interinstitucionais. Em contrapartida, identificou-se uma parcela significativa de autores que não possui nenhum vínculo com os pesquisadores da rede estudada, deixando uma lacuna a ser pesquisada em estudos futuros, com a finalidade de compreender o comportamento desses pesquisadores, analisando suas relações de coautoria tanto nacionais quanto internacionais.

Palavras-chave: Redes; Coautoria; Inovação; Programas de pós-graduação; Administração. 


\title{
AVALIAÇÃO DE UMA EMPRESA HOTELEIRA, COM BASE NOS MÉTODOS DOS MÚLTIPLOS DE MERCADO E DO FLUXO DE CAIXA DESCONTADO EM RONDONÓPOLIS-MT
}

\author{
João Bosco Arbues Carneiro Junior, Elahíne Santos de Moraes, \\ Ramon Luiz Arenhardt, Sofia Ines Niveiros
}

\section{RESUMO}

O propósito desta pesquisa é proporcionar a compreensão da importância da avaliação de empresas, expondo seus variados métodos. A interrogação norteadora é: quais os valores estimados para a avaliação de uma empresa do ramo de hotelaria, utilizando as metodologias dos múltiplos de mercado e do fluxo de caixa descontado? O objetivo da pesquisa é estimar o valor da empresa utilizando estas duas metodologias. Na fundamentação teórica apresenta-se uma visão geral dos diversos modelos de avaliação de empresas e seus pressupostos. A metodologia é caracterizada como descritiva, estudo de caso e quantitativa e amostra é não probabilística. O objeto de estudo é um hotel situado no Distrito Industrial do município de Rondonópolis, no qual foram abordados os critérios de múltiplos de mercado e fluxo de caixa descontado, a fim de sugerir o real valor da empresa. Encontraram-se discrepâncias nos resultados de avaliação diante dos métodos utilizados, no qual ressaltou a superioridade do fluxo de caixa descontado por se aproximar mais da realidade em função de considerar o valor do dinheiro no tempo. Conclui-se que a pesquisa foi relevante aos proprietários da empresa, pois por visualizaram o valor da sua organização e identificaram qual melhor método representou esses valores.

Palavras-chave: Avaliação de empresa; Fluxo de caixa descontado; Hotel

\section{TERCEIRIZAÇÃO NAS INSTITUIÇÕES FEDERAIS DE ENSINO SUPERIOR: O processo de licitação para os serviços terceirizados da Universidade Federal de Pernambuco}

Jose de Arimathea Cabral

\section{RESUMO}

A Constituição Federal estabelece que toda contratação pública deve ser realizada através da licitação. Este trabalho apresenta uma análise sobre os procedimentos para as contratações públicas dos serviços terceirizados nas instituições federais de ensino superior, tomando como referência os processos de contratações de serviços terceirizados, na Universidade Federal de Pernambuco. No desenvolvimento do trabalho, tomou-se com referencial teórico os conceitos de licitação, expondo um breve histórico da licitação pública e as legislações que regulam as contratações públicas. Para isso, percorreu o caminho metodológico da abordagem qualitativa por meio de pesquisa bibliográfica e documental, tendo a base teórica sido fundamentada em trabalhos já publicados e pertinentes ao tema da pesquisa e nas legislações regulatórias da licitação pública. O resultado alcançado foi produto de pesquisa documental realizada na unidade administrativa Diretoria de Licitação e Contratos que é subordinada à Pró Reitoria de Gestão Administrativa da UFPE, onde foram analisados os processos de contratação de empresas especializadas na prestação de serviços. Da análise, verifica-se que a contratação pública não é tarefa simples e não se concretiza em tempo hábil e que requer profundo conhecimento das partes envolvidas e ainda enfrenta uma burocracia lenta e onerosa.

Palavras-chave: Contratação Pública; Serviços Terceiros; Gestão Pública 


\section{O JEITINHO BRASILEIRO: Analisando suas características como ferramenta de conveniência social}

Rafaela Simoes Egito, Wilka Ferreira Monteiro

\section{RESUMO}

Um aspecto cultural marcante na sociedade brasileira, o denominado "jeitinho brasileiro" é o típico processo por meio da habilidade, e engenhosa manobra que alguém torna possível o impossível, justo o injusto, legal o ilegal (GUERREIRO RAMOS, 1983). A finalidade deste estudo foi confrontar as abordagens de diversos autores que já discorreram sobre o assunto e buscar compreender se afinal poderia ser cogitado como alternativa válida o uso desse dito "jeitinho" como uma saída viável e aceitável na resolução dos problemas internos e característicos da Gestão Pública ou se, de modo algum poderia ser tolerado tal comportamento, uma vez que se configuraria como grave afronta e transgressão aos direitos e garantias fundamentais expressados pelos princípios da Administração Pública. Para isso, foi realizado levantamento sobre a temática em literatura especializada, além de pesquisa em material disponível nas bases de periódicos da Capes, Scielo, e na BDTD (Biblioteca Digital Brasileira de Teses e Dissertações). Além do uso dos descritores: "Aspectos culturais", "formalismo" e "jeitinho brasileiro", "criatividade" e "flexibilidade". De maneira geral, percebeu-se que o jeitinho pode ser analisado como um produto do formalismo de maneira positiva ou negativa de acordo com a conveniência social.

Palavras-chave: Aspectos culturais, Formalismo, Jeitinho, Cultura Organizacional, Gestão Pública.

\section{EVASÃO UNIVERSITÁRIA NO ENSINO À DISTÂNCIA: Análise dos fatores influenciadores}

Thaís Santos Martins

\section{RESUMO}

A discussão sobre o tema evasão universitária tem sido uma realidade recorrente na área da Educação no Brasil e em várias partes do mundo. Nesse contexto, assume centralidade o ensino à Distância, pois tem sido considerada uma alternativa de acesso ao ensino superior. Assim, este trabalho tem por objetivo analisar as principais razões de evasão nos 18 cursos do polo de educação à distância da Anhanguera Uniderp na cidade de Rondonópolis-MT. A coleta de dados foi realizada em dois momentos. Primeiramente, por meio de entrevistas semiestruturadas com o diretor e os coordenadores dos cursos, e depois, por meio de um questionário eletrônico enviado aos alunos. No tratamento dos dados foram utilizados modelos estatísticos abrangendo análise fatorial e comparativo entre médias. Os resultados indicam que há diferenças, estatisticamente significativas a um nível de 0,05, entre as razões de evasão e a situação quando estudava, o estado civil, e que não há diferenças, estatisticamente significativas, entre as razões de evasão e o semestre, o curso, o gênero e o tipo de moradia. Os dados qualitativos apresentam algumas razões não observadas antes. Os resultados das análises quantitativas e qualitativas foram discutidos, conjuntamente, de maneira a reforçar as descobertas desta pesquisa.

Palavras-chave: Educação; Ensino à distância; Evasão. 


\section{Dear Readers}

In the first article, a group of authors, headed by Carlos Sérgio Rodrigues Queiroz, conducted a study to analyze the publications on Diversity Management available on the basis of the Spell platform in the period between 1991 and 2017. The article indicated the authors who published the most, the higher education institutions (IES) associated with these authors and the major journals using a bibliometric research which selected 128 articles that were organized into categories (journal, authors, IES, theme, research approach). The results engendered actually indicate the competitive and strategic importance to organizations as they study diversity and organizational learning. The second article, written by Mirella Vicente de Carvalho, Diogo Barbosa Leite and Silvana Santos da Cruz, discusses what parents value during the search of a school and/or nursery for their children. The fundamental objective was to investigate the process of choosing and the purchase behavior of the clients of the analyzed school. The main results are related to the peculiarities of the segment, being the groups of reference extremely important to these consumers. The authors found that more than through communication, these consumers are guided by indications from people for whom they report credibility. They also found that these parents, different from what the school manager herself said, do not pursue Social status when they seek their children's school, but institutions that care for educational methodology. Camila Bittencourt do Nascimento and Arilda Magna Campagnaro Teixeira searched to identify the competencies perceived by the students of Business Administration in the state of Maranhão that were developed during their courses. The authors used a descriptive character research, with cross-sectional cut, through the data collection of primary data by accessibility. The results were obtained through descriptive statistics and multiple linear regression. The descriptive statistics showed that some Public and Private IES students indicated dispersed opinions. The estimates of the regression showed that, for the Public IES, only the Profissiographic Profile was statistically significant to explain the egress profile, but for the Private IES, the variables Profissiographic Profile, Job Description and "working in the administrative area" were statistically significant, at the level of 5\% of confidence. These results suggest that the Public IES students notice less competencies and abilities being developed to them than the Private IES students. The fourth article, conducted by Danieli Artuzi Pes Backes and her students, identified the relationship between the Innovation researchers in the Administration Graduate stricto sensu programs in Brazil, based on the theoretical and methodological approach of Social Network Analysis (SNA), using Ucinet 6 and NetDraw 2160 software. The results showed weak relationships for the formation of the Innovation coauthors network and indicated that some researchers act as central nodes of intra-institutional scientific production while others act as inter bridges. But they also showed that a significant number of authors do not have any link with the researchers in the studied network, leaving a gap to be investigated in future studies. João Bosco Arbues Carneiro Junior, Elahíne Santos de Moraes, Ramon Luiz Arenhardt and Sofia Ines Niveiros had the objective to estimate the value of a hotel located in the Industrial District of Rondonópolis-MT using market multiples and discounted cash flow as methodologies. The authors found discrepancies in the evaluation results in relation to the methods used, in which they emphasized the superiority of discounted cash flow. The research seems to be relevant to the owners of the company, because they visualized the value of their organization and identified which method best represented these values. Jose de Arimathea Cabral presented an analysis of the procedures for contracting public outsourced services at the Federal University of Pernambuco. The qualitative approach was carried out through bibliographical and documentary research, and the result showed that public procurement is not a simple task, since it does not take place in a timely manner and it requires deep knowledge of the parties involved, besides facing a slow and burdensome bureaucracy. Rafaela Simoes Egito and Wilka Ferreira Monteiro discussed a cultural aspect in Brazilian society, the so-called "Brazilian way of doing things" ("jeitinho brasileiro"). The study confronted the approaches of several authors who have already discussed the subject and tried to understand if this "way" could be considered a valid alternative as a viable and acceptable solution in solving internal and typical problems of Public Management, or either such behavior could in any way be tolerated, since it would constitute a serious affront and transgression of the fundamental rights and guarantees expressed by the principles of Public Administration. For that, a survey was carried out on the subject matter in specialized literature and, in a general way, it was perceived that the "jeitinho" can be analyzed as a product of formalism in a positive or negative way, according to the social convenience. In the last article, Thais Santos Martins discussed the evasion in higher education in 18 courses of the Distance Learning Hub at Anhanguera Uniderp in Rondonópolis-MT. Statistic models were used covering factorial analysis and comparative analysis between average numbers. The results showed significant statistic differences at 0,05 level between the evasion and the situation when these students were studying, and marital status, and there was no significant difference between evasion and semester, course, gender and type of housing. Qualitative data showed some reasons not observed before. The author indicated that results of the quantitative and qualitative analysis were discussed together, with the purpose of reinforcing the discoveries of the research.

We hope the results of the research presented here serve as the basis for new articles. Prof. Dr. André Luís Janzkovski Cardoso 
Editorial

ANALYSIS OF THE LITERATURE OF THE SPELL JOURNAL BASIS ON THE THEMATIC MANAGEMENT OF DIVERSITY
Carlos Sérgio Rodrigues Queiroz, Geice Souza dos Santos, Luciene de Jesus e Silva Soares, Vanessa da Silva Ossuna, Marciane Silva Pereira
IN SEARCH OF THE IDEAL SCHOOL: The reasons to be taken into account for a better choice
Mirella Vicente de Carvalho, Diogo Barbosa Leite, Silvana Santos da Cruz

\section{MANAGER SKILLS DEVELOPED DURING UNDERGRADUATE IDENTIFIED BY THE STUDENTS}

\section{3}

Camila Bittencourt do Nascimento, Arilda Magna Campagnaro Teixeira

THE NETWORK OF CO-AUTHORIES FORMATION IN THE SCIENTIFIC PRODUCTION OF INNOVATION IN THE BRAZILIAN PPGAs

VALUATION OF A HOTEL COMPANY, BASED ON THE METHODS OF RELATIVE VALUATION AND DISCOUNTED CASH FLOW IN RONDONÓPOLIS-MT
Danieli Artuzi Pes Backes, Jessica Fernanda Yoshida de Freitas, Manuela de Carvalho e Barbosa, Mateus de Carvalho e Barbosa
OUTSOURCING IN FEDERAL INSTITUTIONS OF HIGHER EDUCATION: The bidding process for the outsourced services of the Federal University of Pernambuco
108

João Bosco Arbues Carneiro Junior, Elahíne Santos de Moraes, Ramon Luiz Arenhardt, Sofia Ines Niveiros
THE BRAZILIAN WAY: Analyzing its characteristics as a tool of social convenience Wilka Ferreira Monteiro
UNIVERSITY EVASION IN DISTANCE LEARNING: Analysis of factors influencing 


\title{
ANALYSIS OF THE LITERATURE OF THE SPELL JOURNAL BASIS ON THE THEMATIC MANAGEMENT OF DIVERSITY
}

\author{
Carlos Sérgio Rodrigues Queiroz, Geice Souza dos Santos, Luciene de Jesus e Silva Soares, \\ Vanessa da Silva Ossuna, Marciane Silva Pereira
}

\begin{abstract}
The use of the term diversity has been constant in organizational studies, because management is closely related to the management of diversity. Thus, the purpose of this article is to analyze the publications on Diversity Management available on the basis of the Spell platform in the period between 1991 and 2017, to verify the periods, reporting the authors who published the most, the higher education institutions associated with these authors and the major journals. Thus, this is a bibliometric research, with predominantly quantitative approach and brief qualitative aspect. After the appropriate filters on "Diversity Management", 128 articles were selected and organized into categories (journal, authors, IES, theme, research approach). The results engendered actually indicate the competitive and strategic importance to organizations as they study organizational learning. It is hoped that this survey can contribute to demonstrate the scenario of scientific production on Management of diversity and provide reflection on the possible courses and limitations in the organizational context. As a limitation, the analysis in only one database stands out.
\end{abstract}

Keywords: People Management; Art Studies; Bibliometric Research.

\section{IN SEARCH OF THE IDEAL SCHOOL: The reasons to be taken into account for a better choice}

Mirella Vicente de Carvalho, Diogo Barbosa Leite, Silvana Santos da Cruz

\begin{abstract}
In search of a basis for what parents value during the search of a school and / or nursery for their children, an assessment was carried out in a certain school to evaluate what the influence factors of the educational institution are. The fundamental objective is to investigate the process of choosing and the purchase behavior of the clients of the analyzed school. The research was divided in two parts: the first is characterized as an explanatory-purposed case study, using a qualitative approach and a semistructured script applied to the school manager as a data collection instrument; The second phase is configured as a survey, with a descriptive objective, and a quantitative approach based on a structured questionnaire applied to the students' parents. The study was cross-sectional and data were collected in February 2017. The main results are related to the peculiarities of the segment, being the groups of reference extremely important to these consumers. It has been found that more than through communication, these consumers are guided by indications from people for whom they report credibility. It was also found that these parents, different from what the manager herself said, do not seek Social status when they seek their children's school, but institutions that care for educational methodology.
\end{abstract}

Keywords: Process of choice. Factors of choice. Buying behavior. Satisfaction. Educational Institution. 


\title{
MANAGER SKILLS DEVELOPED DURING UNDERGRADUATE IDENTIFIED BY THE STUDENTS
}

\author{
Camila Bittencourt do Nascimento, Arilda Magna Campagnaro Teixeira
}

\begin{abstract}
This paper aimed to identify the competencies perceived by the students of Business Administration in the state of Maranhão that were developed during their courses. It is justified because it will add an angle of discussion on the qualities of these courses - the student perception about the competencies while the current researches concentrated on the quality of the courses. It was used a descriptive character research, with cross-sectional cut, through the data collection of primary data by accessibility. The results were obtained through descriptive statistics and multiple linear regression. The descriptive statistics showed that some Public and Private IES students tended to agree on the development of the competencies and habilities; while others did not - the standard-deviations of the average of the answers indicated dispersion among opinions. The estimates of the regression, at 5\% level of confidence, showed that, for the Public IES, only the Profissiographic Profile showed statistically significant to explain the egress profile. For the Private IES, the variables showed statistically significant, at the level of 5\% of confidence, Profissiographic Profile, Job Description and "working in the administrative area". These results suggest that the Public IES students notice less competencies and abilities that are being developed to them than the Private IES students.
\end{abstract}

Keywords: Higher Education; Business Administration; Competencies Development; Perception of students.

\section{THE NETWORK OF CO-AUTHORIES FORMATION IN THE SCIENTIFIC PRODUCTION OF INNOVATION IN THE BRAZILIAN PPGAs}

\author{
Danieli Artuzi Pes Backes, Jessica Fernanda Yoshida de Freitas, Manuela de Carvalho e \\ Barbosa, Mateus de Carvalho e Barbosa
}

\begin{abstract}
This study aimed to identify the relationship between the Innovation researchers in the Administration Graduate stricto sensu programs in Brazil, based on the theoretical and methodological approach of Social Network Analysis (SNA). In order to map the scientific production of co-authorship networks, the Ucinet 6 and NetDraw 2160 software were used to generate the graphs, reaching results that showed weak relationships for the formation of the Innovation coauthors network. However, proactive behavior became clear to some researchers that act as central nodes of intra-institutional scientific production and others that act as inter bridges. In contrast, it was found that a significant number of authors do not have any link with the researchers in the studied network, leaving a gap to be investigated in future studies in order to understand the behavior of these researchers, analyzing their co-authored relations both national and international.
\end{abstract}

Keywords: Networks; Co-authoring; Innovation; Graduate programs; Management. 


\title{
VALUATION OF A HOTEL COMPANY, BASED ON THE METHODS OF RELATIVE VALUATION AND DISCOUNTED CASH FLOW IN RONDONÓPOLIS-MT
}

\author{
João Bosco Arbues Carneiro Junior, Elahíne Santos de Moraes, \\ Ramon Luiz Arenhardt, Sofia Ines Niveiros
}

\begin{abstract}
The purpose of this research is to provide the understanding of the importance of the evaluation of the company, by exposing their varied methods. The guiding question is: what are the estimated values for the evaluation of a hotel business, using the methodologies of market multiples and discounted cash flow? The objective of the research is to estimate the value of the company using these two methodologies. The theoretical basis presents an overview of the various models of corporate assessment and their assumptions. The methodology is characterized as descriptive, case study and quantitative and sample is non-probabilistic. The object of study is a hotel located in the Industrial District of Rondonópolis, in which the criteria of market multiples and discounted cash flow were approached, in order to suggest the real value of the company. Found discrepancies in the evaluation results in relation to the methods used, in which it emphasized the superiority of discounted cash flow because it came closer to reality because of considering the value of money over time. It was concluded that the research was relevant to the owners of the company, because they visualized the value of their organization and identified which best method represented these values.
\end{abstract}

Keywords: Valuation; Discounted cash flow; Hotel.

\section{OUTSOURCING IN FEDERAL INSTITUTIONS OF HIGHER EDUCATION: The bidding process for the outsourced services of the Federal University of Pernambuco}

Jose de Arimathea Cabral

\begin{abstract}
The Federal Constitution establishes that all public contracts must be carried out through bidding. This paper presents an analysis of the procedures for contracting public outsourced services in federal institutions of higher education, taking as reference the contracting processes of outsourced services, at the Federal University of Pernambuco. In the development of the work, the concepts of bidding were taken as theoretical reference, exposing a brief history of the public bidding and the legislations that regulate the public hirings. For that, the qualitative approach was carried out through bibliographical and documentary research, and the theoretical basis was based on papers already published and pertinent to the research topic and in the regulatory legislation of public bidding. The result was a documentary research product carried out at the Administrative Unit for Procurement and Contracts, which is subordinated to the UFPE Administrative Management Office, where the processes of hiring companies specialized in the rendering of services were analyzed. The analysis shows that public procurement is not a simple task and does not take place in a timely manner and requires deep knowledge of the parties involved and still faces a slow and burdensome bureaucracy.
\end{abstract}

Keywords: Public Procurement; Third Party Services; Public Administration 
THE BRAZILIAN WAY: Analyzing its characteristics as a tool of social convenience

Rafaela Simoes Egito, Wilka Ferreira Monteiro

\begin{abstract}
A striking cultural aspect in Brazilian society, the so-called "Brazilian way of doing things" is the typical process through skill, and ingenious maneuvering that makes possible the impossible, just the unjust, legal the illegal (GUERREIRO RAMOS, 1983). The purpose of this study was to confront the approaches of several authors who have already discussed the subject and to try to understand if, after all, a valid alternative could be considered as the use of this "way" as a viable and acceptable solution in solving problems internal and characteristic of Public Management or weather such behavior could in any way be tolerated, since it would constitute a serious affront and transgression of the fundamental rights and guarantees expressed by the principles of Public Administration. For that, a survey was carried out on the subject matter in specialized literature, as well as a research on material available on Capes, Scielo, and BDTD (Brazilian Digital Library of Theses and Dissertations) journals. Besides the use of the descriptors: "Cultural aspects", "formalism" and "Brazilian way", "creativity" and "flexibility". In a general way, it was perceived that the "jeitinho" can be analyzed as a product of formalism in a positive or negative way, according to the social convenience.
\end{abstract}

Keywords: Cultural Aspects; Formalism; Brazilian Style; Brazilian way; Organizational Culture; Public Management.

\title{
UNIVERSITY EVASION IN DISTANCE LEARNING: Analysis of factors influencing
}

Thais Santos Martins

\begin{abstract}
The theme of the evasion on higher education has become a real concern and a reality in Brazil's educational area and other parts of the world. In this context, Distance Learning assumes the centrality, because it has been considered an alternative to get access to higher education. Thus, the objective of this paper is to analyze the main reasons for the evasion in 18 courses of the Distance Learning Hub at Anhanguera Uniderp in Rondonópolis - MT. The data collection took place in two moments. First, by semi-structured interviews with principals and coordinators of the institution, later, by sending an electronic questionnaire to students. During the consideration of the data, statistic models were used covering factorial and comparative analysis between average numbers. The results show significant statistic differences at 0,05 level between the evasion and the situation when these students were studying and marital status, and there is no significant difference between evasion and semester, course, gender and type of housing. Qualitative data have some reasons not observed before. The results of the quantitative and qualitative analysis were discussed together, with the purpose to reinforce the discoveries of the research.
\end{abstract}

Keywords: Education; Distance Learning System; Evasion. 